\title{
Integrated Marketing Communication to Increase Brand Equity: The Case of a Thai Beverage Company
}

\author{
Kulachet Mongkol
}

\begin{abstract}
The objective of this research is to examine the correlation between integrated marketing communication and the brand equity of a Thai beverage company. The findings contribute to a more effective marketing strategy plan for a company.

The sample for this study consisted of four hundred participants who were customers of the company, and questionnaires were used as a research instrument. In order to test the research's hypotheses, Pearson's correlation coefficient was conducted to investigate the correlation between the integrated marketing communication and the company's brand equity.

The results of the hypothesis reveal that there is a direct correlation between the integrated marketing communication and brand equity. Therefore, it is recommended that different types of integrated marketing communication should be appropriately selected in order to efficiently improve brand equity.
\end{abstract}

Index Terms-Brand equity, integrated marketing communication, beverage company

\section{INTRODUCTION}

The beverage industry in Thailand is a very competitive market. A report from Lief International, an export trading company, reveals that the younger generations are increasingly sophisticated consumers in this industry. Factors influencing their buying choices are an increasing urban lifestyle, an awareness of product alternatives, a preference for environmentally-friendly product, and a preference for healthier beverage [1]. Each firm has tried to satisfy its consumers by using different approaches.

Effective strategic management from the management level has proved a valuable instrument which helps firms to achieve their objectives, and firms have tried to execute different strategies in order to gain more competitive advantage. However, as important as effective strategic management are marketing strategies to increase sales volume and market share. Integrated marketing communication (IMC) has been used as tool of the marketing strategies. Therefore, this study aims to investigate the correlation between IMC and a firm's brand equity in order to help the firm to identify appropriate marketing strategies which can create more competitive advantage.

\section{OBJECTIVES OF THE STUDY}

To study the correlation between integrated marketing

Manuscript received May 24, 2014; revised July 22, 2014

Kulachet Mongkol is with the College of Graduate Study in Management, Khon Kaen University, Thailand (e-mail: kulamo@kku.ac.th). communication and the firm's brand equity.

\section{RELEVANT CONCEPTS AND THEORIES}

Many scholars such as Aaker [2], Ailawadi, Lehmann and Neslin [3], and Aaker [4] views brand equity as the set of assets and liabilities linked to a brand's name and symbol that adds to or subtracts from the value provided by a product or service to a firm and/or that firm's customers while Kotler and Keller [5] puts forth a somewhat narrower perspective, contending that a brand has positive customer-based brand equity when consumers react more favorably to a product and the way it is marketed when the brand is identified than when it is not. In particular, Aaker [6] noted that brand equity is composed of five dimensions which are brand awareness, brand's perceived quality, consumer association, and brand loyalty.

To enhance brand equity, the integrated marketing communication concept from Kotler and Keller [5] can be brought to use as a potential strategy that helps firms to have or to increase their brand equity as confirmed by Schultz [7] who contends that brand equity is not merely built through an individual form of communication (such as promotion ,advertising, or direct marketing), but is created by managing brand equity contacts by IMC. However, Kotler has recently updated the model, and therein, several IMC tools have been added. It appears that previous research studies on the relationship between IMC and brand equity have yet to be further explored, since they only examined five marketing tools, namely, advertising, promotion, direct marketing, personal selling and public relations (such as researches from Brunello in 2013 [8], and from Stahl, Heitmann, Lehmann, and Neslin, in 2012 [9]), when in the revised model, IMC is identified as consisting of advertising, promotion, event marketing, public relations, direct marketing, personal selling, word of mouth marketing and interactive marketing. Moreover, in the literature, the beverage industry has been neglected. To fill the void, this research examines their relationship in a Thai beverage company by focusing on the current IMC concept of Kotler and Keller.

\section{RESEARCH FRAMEWORK}

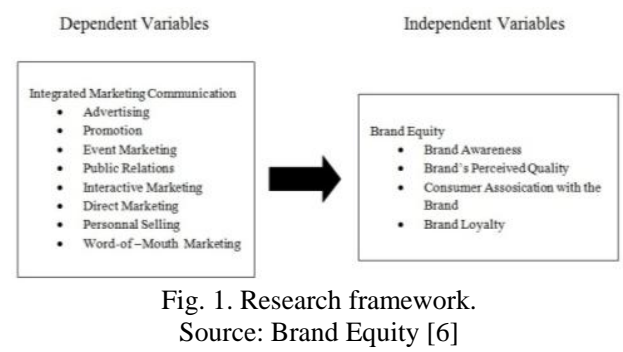




\section{DEFINITIONS}

To illustrate the research framework (Fig. 1), several significant words are defined as following:

Integrate marketing communication is (IMC) is the marketing tool of consistent brand messaging across both traditional and non-traditional marketing channels and using different methods to reinforce each other. In particular, it consisted of advertising, promotion, event marketing, public relations, direct marketing, personal selling, word of mouth marketing and interactive marketing.

Brand equity is the commercial value which comes from perception of customers of the brand name of a particular service or product. In addition, brand equity generally does not come from the service or product itself. It consists of brand awareness, brand's perceived quality, consumer association with the brand, and brand loyalty.

\section{Methodology}

This is essentially a survey research on Integrated Marketing Communication and Brand Equity. Research data came from both primary and secondary sources.

\section{A. Population and Samples}

The study population included all the customers of the beverage company in Thailand which were uncountable. Thus, from the formula [10]

$$
n=\frac{P(1-P) Z^{2}}{d^{2}}
$$

$n=$ Sample size

$P=$ the population proportion (assumed to be .50 since this would provide the maximum sample size)

$d=$ error acceptance

$Z=$ the degree of accuracy expressed as a proportion (.05)

$$
\begin{gathered}
n=\frac{0.5(1-0.5)(1.96)^{2}}{(0.05)^{2}} \\
n=385
\end{gathered}
$$

According to the formula, the samples were 385 respondents (Level of confidence $=95 \%$ ). However, for safety reason, four hundred respondents were conducted in this study. Questionnaires were distributed to respondents who lived in 4 different regions which were north, east, west, and south. After that, non-probability sampling was done using the convenience technique [11].

\section{B. Creating Research Tool}

The research tool was created in the form of questionnaires, and it was divided into three parts.

Part 1: The demographic information of respondents

Part 2: Integrated marketing communication, adapted from theories by Kotler and Keller [5]

Part 3: Brand equity, adapted from Aaker [6]

Part 4: Respondents' comments on creating the brand equity

Questions in part one were arranged in an nominal scale, asking generally demographic information of respondents such as sex, age, marital status, education, types of work, and salary while questions in part two and three were arranged in an ordinal scale with five levels of rating scale: very high, high, neutral, low, and very low.

Scoring criteria of respondents' perception on both integrated marketing communication and brand equity is as follows:

Average score 4.21 - 5.00 means Very high

Average score 3.41 - 4.20 means High

Average score 2.61 - 3.40 means Neutral

Average score 1.81 - 2.60 means Low

Average score 1.00 - 1.80 means Very low

Questionnaires were handed out to 5 specialists to verify the content validity by identifying the Index of Item Objective Congruence (IOC) by choosing questions with an index of higher than 0.50 [11]. In relation to the reliability of the research tool, a reliability analysis was done by determining Cronbach Alpha which equaled to 0.856.

\section{DATA ANALYSIS}

All data were analyzed by both descriptive statistics and inferential statistics. In particular, descriptive statistics is a method used for general analysis on respondents, i.e. percentage, measures of central tendency such as mean, measures of dispersion such as standard deviation while Pearson's correlation coefficient was conducted as inferential statistics in order to investigate the correlation between the integrated marketing communication plan and the company's brand equity.

\section{CONCLUSION}

Part 1: Demographic information

TABLE I: THE CONCLUSION OF RESPONDENTS' GENDER INFORMATION

\begin{tabular}{|c|c|}
\hline Gender & Percentage \\
\hline Male & 67.5 \\
\hline Female & 32.5 \\
\hline Total & 100 \\
\hline
\end{tabular}

TABLE II: THE CONCLUSION OF RESPONDENTS'A AGE INFORMATION

\begin{tabular}{|c|c|}
\hline Age & Percentage \\
\hline $21-35$ years & 28 \\
\hline $36-40$ years & 32 \\
\hline 41-55 years & 22 \\
\hline Over 55 years & 18 \\
\hline Total & 100 \\
\hline
\end{tabular}

TABLE III: THE CONCLUSION OF RESPONDENTS’ MARITAL STATUS INFORMATION

\begin{tabular}{|c|c|}
\hline Marital Status & Percentage \\
\hline Single & 25 \\
\hline Married & 65 \\
\hline Divorce & 8 \\
\hline Others & 2 \\
\hline Total & 100 \\
\hline
\end{tabular}


TABLE IV: THE CONCLUSION OF RESPONDENTS' EDUCATION INFORMATION

\begin{tabular}{|c|c|}
\hline Education & Percentage \\
\hline Under Bachelor's Degree & 10 \\
\hline Bachelor's Degree & 64.5 \\
\hline Master's Degree & 18.5 \\
\hline Over Master's Degree & 7 \\
\hline Total & 100 \\
\hline
\end{tabular}

TABLE V: THE CONCLUSION OF RESPONDENTS' OCCUPATION INFORMATION

\begin{tabular}{|c|c|}
\hline Occupation & Percentage \\
\hline Student & 12.2 \\
\hline Government Officer & 8 \\
\hline Private company officer & 52.7 \\
\hline Business Owner & 18.1 \\
\hline Others & 9 \\
\hline Total & 100 \\
\hline
\end{tabular}

TABLE VI: THE CONCLUSION OF RESPONDENTS’ INCOME INFORMATION

\begin{tabular}{|c|c|}
\hline Income (baht per month) & Percentage \\
\hline Under 10,000 & 2 \\
\hline $10,000-20,000$ & 9 \\
\hline $20,001-30,000$ & 10.25 \\
\hline $30,001-40,000$ & 15.25 \\
\hline $40,001-50,000$ & 59.5 \\
\hline Over 50,000 & 4 \\
\hline Total & 100 \\
\hline
\end{tabular}

According to Table I-Table VI, the findings revealed that the majority of respondents were male ( 67.5 percent), aged between 36-40 years old (32 percent), married (65 percent), holding bachelor's degrees (64.5 percent), working for private companies ( 52.7 percent), and earning approximately 40,001-50,000 baht per month (59.5 percent).

Part 2: Respondents' perception on integrated marketing communication

TABLE VII: RESPONDENTS' PERCEPTION ON INTEGRATED MARKETING COMMUNICATION

\begin{tabular}{|l|c|c|c|}
\hline Types of IMC & $\bar{X}$ & S.D. & Meaning \\
\hline Advertising & 2.88 & 1.063 & Neutral \\
\hline Promotion & 2.81 & 0.693 & Neutral \\
\hline Event marketing & 3.38 & 0.810 & High \\
\hline Public relation & 3.30 & 0.810 & Neutral \\
\hline Direct marketing & 2.56 & 0.677 & Low \\
\hline Personal Selling & 3.83 & 0.831 & High \\
\hline Word of mouth & 3.05 & 0.890 & Neutral \\
\hline Interactive marketing & 2.68 & 1.194 & Neutral \\
\hline
\end{tabular}

Based on the findings in Table VII, only event marketing and personal selling were highly recognized by customers. Advertising, promotion, word of mouth and interactive marketing were moderately effective, creating a neutral level of perception, while direct marketing seemed to be an inefficient type of IMC since customers' perception were at a low level.
Part 3: Respondents' perception on brand equity of the beverage company

TABLE VIII: RESPONDENTS' PERCEPTION ON BRAND EQUITY OF THE BEVERAGE COMPANY

\begin{tabular}{|l|c|c|c|}
\hline Brand Equity & $\bar{X}$ & S.D. & Meaning \\
\hline Brand awareness & 3.76 & 0.604 & Very high \\
\hline Brand's perceived quality & 3.50 & 0.668 & high \\
\hline $\begin{array}{l}\text { Consumer association with } \\
\text { the brand }\end{array}$ & 3.59 & 0.710 & high \\
\hline Brand loyalty & 3.23 & 0.796 & Neutral \\
\hline
\end{tabular}

As shown in Table VIII, brand awareness hit a very high level. Similarly, customers' perception on the brand's perceived quality and Consumer association with the brand appear at the same level, while their perception on brand loyalty was only in neutral level.

\section{Hypothesis Testing Results}

Hypothesis: There was a correlation between integrated marketing communication and brand equity of the firm

H0: There was no correlation between integrated marketing communication and brand equity of the firm

H1: There was a correlation between integrated marketing communication and brand equity of the firm

TABLE IX: CORRELATION BETWEEN INTEGRATED MARKETING COMMUNICATION AND BRAND EQUITY OF THE FIRM

\begin{tabular}{|l|c|}
\hline \multicolumn{2}{|c|}{ COMMUNICATION AND BRAND EQUITY OF THE FIRM } \\
Communication (IMC) & Correlation with the Brand Equity \\
\hline Advertising & 0.233 \\
\hline Sales Promotion & $0.052^{*}$ \\
\hline Event Marketing & $0.381^{*}$ \\
\hline Public Relations & $0.015^{*}$ \\
\hline Interactive Marketing & $0.330^{*}$ \\
\hline Direct Marketing & $0.121^{*}$ \\
\hline Personal Selling & $0.091^{*}$ \\
\hline Word-of -Mouth Marketing & $0.486^{*}$ \\
\hline The overall of IMC & $0.290^{*}$ \\
\hline
\end{tabular}

*significant level at .05

The results shown in Table IX suggest that that sales promotion, event marketing, public relations, interactive marketing, direct marketing personal selling and word of mouth marketing were directly related to brand equity. In contrast, advertising was the only tool which was not related to brand equity.

Part 4: Respondents' comments on creating the brand equity

Most of respondents agreed that IMC can create the firm's brand equity. Nevertheless, they essentially prefer personal selling since they contend that staffs always have quick response to their needs, and they feel secure to do business with the firm.

\section{DISCUSSION}

The results from hypothesis testing suggest that there was 
a correlation between integrated marketing communication and the brand equity. This is in line with Aaker [2], Kotler and Keller [5], Kumar [12], Raggio and Leone [13] and Aaker [4], who agreed that firms could create their brand equity by implementing IMC. They contended that IMC encouraged customers to aware and perceive quality of products and services. In particular, the results showed that every IMC tool except advertising was related to the brand equity in the same direction. Such an observation is also attested in Tanittanakorn [14], which shows word of mouth was one of the most efficient tools of marketing since the cost of word of mouth was normally low. This in turn provided more reliability than other types of IMC because word of mouth always came from people who perceived the quality of the brand. Furthermore, the results can be also related to the study of Tanittanakorn [14], where it is argued that event marketing was an efficient marketing tool that penetrated targets, and to the study of Changchooto [15], which finds interactive marketing or online marketing plays an important role in terms of introducing products' information. It is indeed a contemporary tool which could efficiently access new customers in the digital age.

However, it is interesting to note that advertising is not necessarily related to brand equity even though this component of the promotion strategies is generally believed to be effective and even though firms spend most of the marketing budget on such a component. It is found that this particular research result is in line with Brunello [8] who confirms that nowadays specialists consider advertising ineffective because of high cost involved and the unpredictable target audience, and firm tends to focus more on other types of communication strategy. This unexpected finding may be attributed to the fact that educated customers are wary of advertising since they realize that some messages from advertising involve some kind of exaggeration, tending to perceive it as a propaganda. Nelson [16], for example, views a propaganda as a systematic form of purposeful persuasion that attempts to influence the emotions, attitudes, opinions, and actions of specified target audiences for ideological, political or commercial purposes through the controlled transmission of one-sided messages (which may or may not be factual) via mass and direct media channels. Therefore, it can be concluded that in some cases, advertising may not turn out to be an appropriate IMC tool to enhance brand band equity, especially when customers do not rely on the media.

\section{RECOMMENDATION FROM THE STUDY}

This study reveals that the perception of customers on direct marketing of this beverage company is in the low level range; thus, the company should pay more attention on such an IMC tool which consists of advertising, promotion, event marketing, public relation, direct marketing, personal selling, word of mouth, and interactive marketing. In particular, personal selling should be more focused since the findings show that it was highly recognized by customers. Nevertheless, because there seems to be no correlation between advertising and the brand equity of the firm, marketers should revisit the issue of advertising budget. In addition, as we have realized that the advertising costs especially in television media or billboard are considerably high; thus, reducing the advertising cost can definitely help firms to lower their total cost, and this leads firms to gain more competitive advantage.

\section{RECOMMENDATION FOR FUTURE STUDY}

1) Rather than IMC, different marketing tools should be explored whether they could be able to create firms' brand equity.

2) The same conceptual framework of this study should be examined with different industries in order to confirm if IMC really create brand equity.

3) Since this study reveals that advertising somehow does not create the firm's brand equity; therefore, future study should pay more attention on this marketing tool. Furthermore, a qualitative study using in-depth study can help a researcher to have more understanding on brand equity creation.

\section{REFERENCES}

[1] Lief Internationa. (2014). [Online]. Available: http://www.liefinternational.com/blog/market-research/consumer-tren ds/thailand/beverage-industry-trends-in-thailand/

[2] D. A. Aaker, Strategic Market Management, New York: Wiley, 2013.

[3] K. L. Ailawadi, D. R. Lehmann, and S. A. Neslin, "Revenue premium as an outcome measure of brand equity," Journal of Marketing, vol. 67 pp. 1-17, October 2003.

[4] D. A. Aaker, "The Value of Brand Equity," Journal of Business Strategy, vol. 13, iss: 4, pp. 27-32, 1992.

[5] P. Kotler and K. Keller, Marketing Management, Prentice Hall, 2012.

[6] D. A. Aaker, Managing Brand Equity, New York: Free Press, 1991.

[7] D. E. Schultz, "A clean brand slate," Marketing Management, pp. 10-11, September/October 2004.

[8] A. Brunello, 'The relationship between integrated marketing communication and brand equity," International Journal of Communication Research, vol. 3, issue 1, pp. 9-14, January / March 2013.

[9] F. Stahl, M. Heitmann, R. D. Lehmann, and A. S. Neslin, "The impact of brand equity on customer acquisition, retention, and profit margin," Journal of Marketing, vol. 76, no. 4, July 2012.

[10] W. G. Cochran, Sampling Techniques, New York, 1977.

[11] G. W. Zikmund, Business Research Methods, 7th Edition, Cengage Learning, 2002.

[12] M. Kumar, "Separation of brand equity and brand value," Global Business Review, vol. 11, no. 3, pp. 421-434, October 2010.

[13] D. R. Raggio and P. R. Leone, "The theoretical separation of brand equity and brand value: Managerial implications for strategic planning," Journal of Brand Management, pp. 380-395, March 2007.

[14] N. Tanittanakorn, "Influence of the internet," Journal of Business Executives, vol. 32, no. 1, pp. 17-22, 2012.

[15] N. Changchooto, Marketing Communication, Bangkok: Bangkok University Press, 2012.

[16] A. R. Nelson, A Chronology and Glossary of Propaganda in the United States, pp. 232-233, 1996.

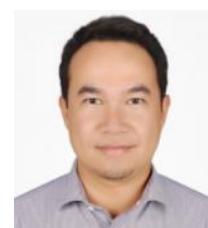

Kulachet Mongkol is currently an assistant professor at the College of Graduate Study in Management, Khon Kaen University, Thailand. Dr. Kulachet received his Ph.D. degree in management from the University of Canberra, Australia and MSA degree in international administration from Central Michigan University, U.S.A. Prior to his appointment at Khon Kaen University, Dr. Kulachet was a deputy director at the Center for Logistics Education and Research, and was an economist at the Fiscal Policy Office, Ministry of Finance, Thailand. His research is primarily in the areas of strategic management, and his work has been published in a number of international academic journals including Research Journal of Business Management and International Journal of Arts and Sciences. 